\title{
Initial Experience with the Utility of the Infrared Diode Laser in Kaduna, Nigeria.
}

\author{
*MAHMOUD A. O., KYARI F., OLOGUNSUA Y.
}

National Eye Centre, P.M.B 2267, Kaduna, Nigeria

\section{SUMMARY}

Our initial clinical experience with the use of a diode laser in the treatment of some retinovascular conditions and refractory glaucoma in some black patients in Kaduna, Nigeria.

Methods: All the 32 eyes of 26 patients treated with diode laser photocoagulation between September 1997 and September 1999, were studied retrospectively. Patient's eye, sex, eye diagnosis. Laser treatment parameters and the intra-operative and post-operative observations were tabulated.

Results: All patients tolerated the laser treatment sessions, although complaints of pain were universal. The follow up observation period ranged from none to one year in this initial study. Eight eyes of 6 patients were treated for proliferative sickle cell retinopathy. Regression of sea fans was observed in all the four eyes $(100 \%)$ of three patients that were available for follow-up observation. However, a fresh sea-fan neo-vascularisation developed elsewhere in the same retina of one of the treated eyes. Of the 12 eyes of 9 patients with diabetic retinopathy, 6 patients ( 8 eyes) were available for follow up.

Among the later group, all eyes but one (87.5\%) had their retinopathy changes stabilised following laser treatment. Two patients with central retina vein occlusion were treated. The only one that was available for follow up was stabilised following treatment. Of the 3 eyes ( 3 patients) that had retinopexy for flat retina breaks, 2 reported for follow up. Both retina breaks remained attached.

All the 6 patients ( 7 eyes) with refractory glaucoma who had contact diode laser treatment did not have the initial reduction in the intra-ocular pressures sustained subsequently.

Conclusion: Diode laser has been found to be useful in treating a number of retinovascular conditions among the black patients studied. Its initial intra-ocular pressure lowering effect was not sustained in refractory glaucoma. However the small pool of patients and the limited period of follow up examination in this study call for caution with these conclusion.

KEYWORDS: Diode laser treatment, sickle cell retinopathy, diabetic retinopathy, retinopexy refractory glaucoma

\section{INTRODUCTION}

The semiconductor infrared diode laser is compact, portable and uses standard electric supply. Its relative affordability and freedom from expensive maintenance makes it the practical choice in developing world settings such as ours. Being also adaptable to transpupillary ${ }^{1}$, transscleral ${ }^{2,3}$, and endo- ocular ${ }^{4}$ uses , the same device ensures most of the laser needs of an ophthalmic unit. It came into use at National Eye Centre, Kaduna, in 1996. The wavelengths of laser in ophthalmic use range from 488$514 \mathrm{~nm}$ (argon blue) through $647 \mathrm{~nm}$ (krypton red), $533 \mathrm{~nm}$ (emerald green) to $810 \mathrm{~nm}$, (diode). (Excimer laser for cornea- $182 \mathrm{~nm}$ and Nd- YAG $-1064 \mathrm{~nm}$ are for specific

*Author for Correspondence uses in the anterior segment). The advantages of the diode laser's relatively longer wavelength over the more established and tested argon laser include, less scattering, better penetration of nuclear sclerosis, better penetration of blood in vitreous, better penetration of hazy vitreous and better penetration of sub - retinal fluid. Some of the disadvantages include more pain, more choroidal oedema, increased risk of choroidal haemorrhage, and poor update by haemoglobins. Diode laser has been found to be as effective, safe, and reliable for endophotocoagulation as argon system ${ }^{4}$, and for diabetic retinopathy ${ }^{5,6}$ In a prospective study on 10 diabetics with proliferative diabetic retinopathy, with one eye treated by diode laser 
panretinal photocoagulation, and the other argon laser, Ulbig and Hamilton ${ }^{5}$ noted that though patients found diode laser treatment more painful, they appreciated the absence of bright flashes of light during therapy. Similarly Balles et al ${ }^{1}$ reported as much as $43 \%$ of 23 treatments in his series complained of moderate to marked pain. The aim of this communication is to share our initial clinical experience with the infrared diode laser in the treatment of a number of retinovascular conditions and refractory glaucoma.

\section{PATIENTS AND METHODS}

A retrospective review of all the 32 eyes that had diode laser treatment (DLT) between September 1997 and September 1999 was done. Patient's age, sex eye diagnosis, laser treatment parameters, intra - operative and post- operative finding were tabulated .

All the patients were treated using the diode laser Iris Medical Oculight*SL as outpatients. For the vascular retinopathies , the mode of delivery was transpupillary, through well-dilated pupils using the slit -lamp adapter and OMRA-S mainster standard retina argon / diode laser contact lens, following instillation of topical anaesthesia . For retinopexy, trans -pupillary slit' - lamp delivery or the trans -sclera mode under local anaesthesia was used depending on the cooperation of individual patient.

All the cases of vascular retinopathies had fundus fluorescein angioscopy (FFA), to aid diagnosis and subsequent monitoring.

Post-therapy, all the patients were prescribed topical steroids. In addition, those that had transscleral application had analgesics as appropriate.

For patients with proliferative sickle cell retinopathy (PSR), who all were of the HbSC genotype, treatment mode depended on FFA findings . Patients with good generalised retinal perfusion had burns spaced one burn diameter apart, from one disc diameter posterior to , and one disc diameter anterior to the sea fan and one o ' clock hour to each of its sides, and without directly obliterating the sea fans or feeder vessel directly?

Patients with extensive capillary dropout and poor retinal perfusion had scatter panretinal photocoagulation (PRP). For all these patients, sufficient energy to produce a heavy intensity grey to white lesion was applied. Patients with very severe non-proliferative (pre-proliferative) and proliferative diabetic retinopathy requiring laser treatment had transpupillary panretinal photocoagulation (PRP) in a scatter fashion. On the average, a $500 \mathrm{um}$ spot size of 0.1 second duration with enough energy $(750-950 \mathrm{~mW})$ to achieve the desired

reaction, in this case, a moderate intensity grey lesion. The eyes that had diabetic retinopathy with clinically significant macular oedema (CSMO) had focal laser appli- cation. Photocoagulation using a spot size of $100 u$ m lasting 0.1 seconds with energy $(400-500 \mathrm{~mW})$ sufficient to produce a low intensity lesion was applied to microaneurysmal lesions in the centres of circinate ring exudates. Total number of burns required ranged from 7 to 18 .

Patients with central retinal vein occulsion (CRVO) had panretinal photocoagulation (PRP), the indications being either established or incipient neovascularisation.

The eyes treated for flat retinal breaks had photoretinopexy with burns of spot size $500 \mathrm{um}$, and of moderate to heavy intensity with enough number of burns to surround the break in a double row.

Patients with refractory glaucoma had transscleral cyclophotocoagulation with an average energy of $1500 \mathrm{~mW}$ lasting 2 seconds, with the burn placed 1.5 millimetres from the limbus and sparing at least one quadrant.

\section{RESULTS}

Thirty-two eyes from 26 patients had diode laser photocoagulation. The indications for laser treatment included proliferative sickle-cell retinopathy (PSR, 8 eyes of 6 patients), diabetic retinopathy (DR, 12 eyes of 9) patients, central retinal vein occlusion (CRVO, 2 eyes of 2 patient), retinal breaks (RB, 3 eyes of 3 patients), and refractory glaucoma (RG, 7 eyes of 6 patients). Eighteen $(72 \%$ were males and $7(28 \%)$ were females. Thirteen patients $(50 \%)$ were referred to our hospital from elsewhere within Nigeria. The follow- up period ranged from none to over one year (mean 6 months), the exact details are as specified in the tables.

All the patients completed the predetermined course of laser treatment successfully.

Complaints of pain were universal, some severe enough to cause postponement of laser sessions. The other complications are case specific and as specified in the tables for the involved patients.

\section{SICKLE CELL RETINOPATHY (SCR)}

All the patients with sickle -cell retinopathy had haemoglobin genotype $\mathrm{SC}(\mathrm{HbSC})$ The laser sessions were tolerated by all the patients. Of the 4 eyes that were seen at follow-up, all (100\%) treated sea fans had regressed with the retina having pigmented laser scars. However in one eye that received localised scatter laser treatment, a fresh sea fan developed elsewhere. 
Table 1 shows the characteristic of the 6 patients ( 8 eyes)

treated.

Table 1: Characteristics of patients with Sickle-cell retinopathy - 6 patients, 8 eyes

\begin{tabular}{|c|c|c|c|c|c|c|c|c|}
\hline $\begin{array}{l}\mathrm{Pt} \\
\text { no }\end{array}$ & $\begin{array}{l}\text { Age } \\
\text { yrs }\end{array}$ & $\operatorname{sex}$ & Diaguosis - RE & Diaguosis -LE & Laser therapy & Side effect & $\begin{array}{r}\text { Treatment } \\
\text { outcome }\end{array}$ & $\begin{array}{l}\text { Follow up } \\
\text { period }\end{array}$ \\
\hline 1 & 27 & $\mathrm{~m}$ & Total HV & sea fan* & Localised scatter & Procedure & $\begin{array}{l}\text { Scars, fresh sea } \\
\text { fan }\end{array}$ & 5 weeks \\
\hline 2 & 49 & $\mathrm{~m}$ & cataract & $\begin{array}{l}\text { sea fan }+\mathrm{VH}+ \\
+ \text { total } \mathrm{VH}\end{array}$ & $\begin{array}{l}\text { Localised scatter } \\
\text { flat retina hole* }\end{array}$ & $\begin{array}{l}\text { Procedure } \\
\text { tolerated }\end{array}$ & Not available & Nil \\
\hline 3 & 41 & $\mathrm{~m}$ & 2sea fans* & $\mathrm{VH}+$ sea fan $*$ & PRP & $\begin{array}{l}\text { Procedure } \\
\text { tolerated }\end{array}$ & Not available & 2days \\
\hline 4 & 44 & $\mathrm{~m}$ & sea fan* & $\begin{array}{l}\text { Complicated } \\
\text { cataract }\end{array}$ & PRP & $\begin{array}{l}\text { Procedure } \\
\text { tolerate }\end{array}$ & $\begin{array}{c}\text { Regressed } \\
\text { neovasculasation }\end{array}$ & 4months \\
\hline 5 & 26 & f & sea fan* & Sea fans* & PRP & $\begin{array}{l}\text { Procedure } \\
\text { tolerated }\end{array}$ & $\begin{array}{c}\text { Regressed } \\
\text { neovaxularisation }\end{array}$ & 7 months \\
\hline 6 & & $\mathrm{~m}$ & sea fan* & - & PRP & $\begin{array}{r}\text { Procedure } \\
\text { tolerated }\end{array}$ & Not available & Nil \\
\hline
\end{tabular}

* - Indicates treated eye.

PRP - panretinal photocoagulation

VH-vitreosu haemorrhage. 


\section{DIABETIC RETINOPATHY (DR)}

Table 2 shows the characteristics of the 9 patients (12 eyes) treated.

The only eye that was treated because of very severe preproliferative retinopathy has its retinopathy stabilised. Of the three other eyes whose indications for laser treatments were proliferative diabetic retinopathy but with attached retinas, 2 had stable retinopathy while the third continued to exhibit more florid changes. Three eyes had palliative therapy for advanced PDR with tractional retinal detachment while awaiting definitive vitreoretinal management. Two of the 5 eyes that were treated for clinically significant macular oedema (CSMO), that were available for follow up had FFA-proven dry foveae. The laser pro cedure was associated with dispersion of pre-existing blood in one patient and another develop comeal oedema during laser application. These occurrences necessitated temporary delays in the treatment schedules.

Table 2: Characteristic of patients with diabetic retinopthy - 9 patient. 12 eyes.

\begin{tabular}{|c|c|c|c|c|c|c|c|c|}
\hline $\mathrm{Pt}$ & Age & $\operatorname{sex}$ & $\begin{array}{l}\text { Diaguosis - RE Diaguosis } \\
\text { treatment }\end{array}$ & $\begin{array}{l}\text { S-LE Laser Si } \\
\text { outcome }\end{array}$ & ide effect & $\begin{array}{l}\text { Treatment } \\
\text { period }\end{array}$ & Follow up & yrs \\
\hline 1 & 49 & $\mathrm{~m}$ & $\begin{array}{c}\text { Very service } \\
\text { NPDR + CMO* }\end{array}$ & NPDR & PRP & Nil & $\begin{array}{l}\text { Stable } \\
\text { retinopathy }\end{array}$ & 6weeks \\
\hline 2 & 56 & $\mathrm{~m}$ & $\mathrm{VH}$ & PDR + VH* & PRP & $\begin{array}{r}\text { Conaeal } \\
\text { oedema }\end{array}$ & $\begin{array}{l}\text { unrelenting } \\
\text { NVE/NVD }\end{array}$ & Nil \\
\hline 3 & 66 & $\mathrm{~m}$ & PDR-VH & PDR-VH & PRP & $\begin{array}{l}\text { Procedure } \\
\text { well tolerated }\end{array}$ & $\begin{array}{l}\text { Quiescent/stable } \\
\text { retinopathy }\end{array}$ & 9weeks. \\
\hline 4 & 60 & $\mathrm{f}$ & $\begin{array}{l}\text { Complicated } \\
\text { cataract }\end{array}$ & $\begin{array}{l}\text { Advanced PDR } \\
\text { TRD* }\end{array}$ & PRP & nil & - & $\mathrm{Nil}$ \\
\hline 5 & 45 & $\mathrm{~m}$ & $\begin{array}{c}\text { Advanced PDR } \\
\text { + TRD+Optic } \\
\text { neuropathy* }\end{array}$ & $\begin{array}{l}\text { Decompansated } \\
\text { cornea }\end{array}$ & PRP & $\begin{array}{l}\text { Dispersion of } \\
\text { vitreal blood }\end{array}$ & Nil & 4weeks \\
\hline 6 & 66 & $\mathrm{~m}$ & $\begin{array}{c}\text { Advanced PDR } \\
\text { TRD* }\end{array}$ & NPDR & PRP & $\begin{array}{c}\text { Procedure } \\
\text { well tolerated }\end{array}$ & pigmented spots & Nil \\
\hline 7 & 52 & $\mathrm{~m}$ & $\begin{array}{l}\mathrm{CSMO}^{*} \\
\text { TRD }\end{array}$ & Advanced PDR & Focal & $\begin{array}{l}\text { Procedure } \\
\text { well tolerated }\end{array}$ & - & Nil \\
\hline 8 & 54 & f & CSMO* & CSMO* & Focal & nil & Dry fovea & 4weeks \\
\hline 9 & 72 & f & COSMO* & CSMO & Focal & $\begin{array}{l}\text { Procedure } \\
\text { well tolerated }\end{array}$ & - & Nil \\
\hline
\end{tabular}

*- Indicate treated eye

NPDR - Non- proigerative diabetic retinopathy

PDR - Proliferative diabetic retinopathy

COM - Cystoid macular oedema

NVE - Neovascularisation of the disc

CSMO - Clinically significant macular oedema

TRD - Tractional retinal detachment

PRP - Panretinal photocoagulation

VH - Vitreous haemorrhage 
CENTRAL RETINAL VEIN OCCLUSION (CRVO)

Table 3 shows the characteristics of the 2 patients ( 2 eyes ) treated.

Though intra-retinal haemorrhage and oedema had not completely resolved in the eye of the only patient with CRVO and associated extensive retina ischaemia, he had not developed any neo-vascular complication either. The second patient had not been reviewed beyond the day of laser treatment.

Table 3: Characteristics of patients with central retinal vein occlusion (CRVO)-2 patients 2 eyes

\begin{tabular}{ccccccccc}
$\begin{array}{c}\text { Pt } \\
\text { no }\end{array}$ & $\begin{array}{c}\text { Age } \\
\text { yrs }\end{array}$ & sex & Diaguosis - RE & Diaguosis -LE & $\begin{array}{c}\text { Laser } \\
\text { treatment }\end{array}$ & Side effect & $\begin{array}{c}\text { Treatment } \\
\text { outcome }\end{array}$ & $\begin{array}{c}\text { Follow up } \\
\text { period }\end{array}$ \\
\hline 1 & 67 & $m$ & CRVO* & - & PRP & $\begin{array}{c}\text { Procedure well } \\
\text { tolerated }\end{array}$ & $\begin{array}{c}\text { Early } \\
\text { pigmenting } \\
\text { laser spots }\end{array}$ & 6 months \\
2 & 79 & $m$ & - & CRVO* & PRP & $\begin{array}{c}\text { Procedure well } \\
\text { tolerate }\end{array}$ & $\begin{array}{c}\text { Immediately } \\
\text { satisfactory }\end{array}$ & Nil \\
\hline
\end{tabular}

*- Indicaters treated eye.

PRP-panretinal photocoagulation

RETINAL BREAKS.

Table 4 shows the characteristic of the 3 patients ( 3 eyes) treated. All the 3 patients ( 3 eyes) that had retinopexy tolerated the procedure well and the desired burns came through. The retina with breaks in 2 eyes remained attached at the last visits of the 2 patients that were available for follow up monitoring.

Table 4: Characteristics of patients with flat retinal holes - 3 patients 3 eyes

\begin{tabular}{|c|c|c|c|c|c|c|c|c|}
\hline $\begin{array}{l}\text { Pt } \\
\text { no }\end{array}$ & $\begin{array}{l}\text { Age } \\
\text { yrs }\end{array}$ & $\operatorname{sex}$ & Diaguosis - RE & Diaguosis -LE & $\begin{array}{c}\text { Laser } \\
\text { treatment }\end{array}$ & Side effect & $\begin{array}{r}\text { Treatment } \\
\text { outcome }\end{array}$ & $\begin{array}{l}\text { Follow up } \\
\text { period }\end{array}$ \\
\hline 1 & 56 & $\mathrm{~m}$ & $\begin{array}{l}\text { Flat inferior } \\
\text { retinal hole } \\
\text { within lattice* }\end{array}$ & $\begin{array}{l}\text { Paramacular } \\
\text { scar retinopexy } \\
\text { ?toxoplasmosis }\end{array}$ & Transcleral & $\begin{array}{c}\text { Procedure } \\
\text { well tolerateted }\end{array}$ & $\begin{array}{l}\text { Immediately } \\
\text { satisfactory }\end{array}$ & Nil \\
\hline 2 & 52 & $\mathrm{~m}$ & $\begin{array}{l}\text { Flat inferior } \\
\text { horse shoe tear* } \\
\text { Myope }\end{array}$ & - & $\begin{array}{c}\text { Transpulillary } \\
\text { retinopexy }\end{array}$ & $\begin{array}{l}\text { Procedure } \\
\text { well tolerated }\end{array}$ & $\begin{array}{c}\text { Tear remained } \\
\text { flat }\end{array}$ & 12 months \\
\hline 3 & 32 & $\mathrm{~m}$ & $\begin{array}{l}\text { Flat inferior } \\
\text { retinal hole } \\
\text { High myope* }\end{array}$ & - & $\begin{array}{c}\text { Transscleral } \\
\text { retinopexy }\end{array}$ & $\begin{array}{c}\text { Procedure } \\
\text { well tolerated }\end{array}$ & $\begin{array}{c}\text { Tear remained } \\
\text { flat }\end{array}$ & 6 months \\
\hline
\end{tabular}

*-Indicates treated eye. 
REFRACTORY GLAUCOMA

Table 5 shows the characteristics of the patients

Six patients ( 7 eyes) treated for refractory glaucoma did not sustain the initial lowering of their intra-ocular pres sures (IOP) and they had to be recommenced on anti-glaucoma therapy.

Table 5: Characteristics of patients with refractory glaucoma - 6patients. 7 eyes

\begin{tabular}{|c|c|c|c|c|c|c|c|c|}
\hline $\begin{array}{l}\mathrm{Pt} \\
\text { no. }\end{array}$ & $\begin{array}{l}\text { Age } \\
\text { yrs }\end{array}$ & Sex & type & Prela & $\begin{array}{l}\text { IOP } \\
\mathrm{mmHg}\end{array}$ & $\begin{array}{c}\text { Side effect Post laser final } \\
\text { IOP mmHg }\end{array}$ & Follow up period & \\
\hline 1 & 53 & & $\mathrm{~F}$ & Apakic & $\begin{array}{l}\text { RE }-33 \\
L E-42\end{array}$ & $\begin{array}{l}\text { Epithelial } \\
\text { oedema, } \\
\text { Pains }\end{array}$ & $\begin{array}{l}\text { RE }-40 \\
\text { LE }-44\end{array}$ & 4weeks \\
\hline 2 & 37 & & $M$ & $\begin{array}{l}\text { Post-tranmatic } \\
\text { Painful blind eye }\end{array}$ & 50 & Corneal oedema & 32 & 2 days \\
\hline 3 & 26 & & M & Painful blind eye & 34 & Lid oedema & 37 & 5 months \\
\hline 4 & 60 & & $F$ & - & - & - & - & \\
\hline 5 & 75 & & $\mathrm{~F}$ & NVG & 50 & $\mathrm{Nil}$ & 46 & 3 months \\
\hline 6. & 50 & & M & NVG & 44 & Nil & 34 & 1 day \\
\hline
\end{tabular}

NVG - Neovascular glaucoma

LOP - Intraocular pressure

\section{DISCUSSION}

Availability of a diode laser device in our hospital has provided us with a modality for laser treatment of diabetic retinopathy for the first time and alternative treatment modalities for other diseases such as proliferative sickle cell retinopathy(PSR) and retina breaks and refractory glaucoma. As pointed out earlier, the cost is relatively affordable as compared to the argon laser device.

However, even this "affordable" cost may not be within the reach of man other ophthalmic units in developing world settings.

It is relatively maintainance-free, but we wish to point out problem that can crop up as it did once with our device. The near total absence of the technical knowhow in our country may result in the device being out of use for a long time. It took the greater part of the year in 1997, with numerous trans-Atlantic correspondences, to rectify the aforementioned "simple problem. However, the superior logistic advantages cannot be overemphasised. The simple fact that the same device uses standard electrical supply and can be carried from the out patient department to the operating theater obviates the need to duplicate the device in the hospital.

The total number of patients treated could have been much more and the opportunities for follow up assessment could have been more often, were it not for the perennial problem confronting health care delivery in
Nigeria. Not every patient who needed laser could even afford the subsidised introductory fees that we charge, and many could not afford to make the repeated visits necessary for follow up from far-flung locations where they had been referred to Kaduna. Neither did we have adequate telecommunication facilities to contact the patients or their referring doctors to enquire on status of the sizeable proportion of patients population that were not directly available in our clinic for follow up observation. All the eyes seen at follow up ( 4 of 8 eyes) treated for PSR had their sea-fan neovascularisation regressed. With the general practice of abandoning earlier treatment direction to the feeder vessels ${ }^{7}$, we chose to treat eyes without extensive peripheral retinal capillary occlusion with localised scatter laser in and around the sea fan. The only patient who developed neo-vascularisation elsewhere in the same eye merits a mention. This patient had severe PSR with extensive FFA-proven capillary occlusion in one eye and total vitreous haemorrhage in the other eye. He ought to have had generalised scatter treatment to the anterior third of the fundus in the first instance. Efforts are still being made to contact the patient to report back for a more appropriate treatment. Though other workers had indicated the efficacy of transpupillary application of the diode laser in diabetic retinopathy (DR), ${ }^{1,5,6}$ the best we could achieve in our own series was to maintain the stability in diabetic retinopathy changes in 3 of the 4 eyes that were available for follow up. This is because all of them presented in advanced stages with tractional retinal detachment (TRD) in each eye. 
The resort to giving palliative treatment to the flat portions of the retinas with TRD is derived from one of the authors' experience (AOM). The technicalities of vitreoretinal surgery, particularly the removal of posterior vitreous cortex tend to be much easier in eyes that have had previous laser treatment compared to those without previous treatment before vitreoretinal surgery. More so, from past experience, most patients referred for vitreoretinal surgery were unlikely to be able to access these centres elsewhere (generally abroad) for logistics and / or financial reasons. Concerning patients with diabetic maculopathy we restricted the application of diode laser treatment to only those we could apply focal treatment to FFA- proven leaking microaneurysmal lesions. Lack of angiographic photographic facilities for making accurate and permanent recordings limited parafoveal laser treatment including for choroidal neovascularisation in age- related macular degeneration. Even though the diode laser emission at $810 \mathrm{~nm}$ is not absorbed by haemoglobin, the leaking microaneurysms were sealed up in our series. The explanation for this is that transmitted heat from retinal burns congeals these microneurysmal lesions rather than from the direct effect of laser. Our experience with the effectivity of the laser in sealing leaking microaneurysms was also shared by Ulbing, McHugh and Hamilton. ${ }^{8}$ The superior advantage of the diode laser when coupled with Indocyanine green angiography in detecting and treating choroidal neovascularisation' could not be demonstrated by us as we lack the necessary facilities. Concerning the patient with CRVO and severe generalised retinal oedema and widespread haemorrhages, though we are aware that the retinal haemorrhage would limit transimission of the laser energy, we could not delay the treatment further because of the FFA-proven widespread retina ischeamia. Though the recommendation of the CRVO study group ${ }^{8}$ is for a careful observation with frequent follow up examination in the early months of CVRO, with resort to prompt panretinal treatment when rubeosis irides occurs. We could not practise this in a country like Nigeria where there is near-total absence of adequate transport and communication facilities for our patients to report promptly and frequently for such observations.

All the patients who had retinopexy had the decision to have laser treatment made for them by their referring ophthalmologists. It is gratifying to note that the treated breaks, remained attached and a symptomatic at follow up visit for the two patients that were available However, we wish to point out that a number of retinal practitioners ${ }^{11}$ including our humble selves would advise for mere observation of such non-threatening asymptomatic flat retinal holes.

Mention of successful use of transscleral cyclophotocoagulation in glaucoma has been in the non- refractory types ${ }^{3}$ unlike our patients in this series. We believe that we followed the recommended procedures and duration in effecting therapy in these patients. Even then, all of them had reverted back to their pre-laser high IOP levels.

In conclusion, within the limit of this study, we have found the diode laser to be useful in treating a number of retinovascular conditions among black patients in Kaduna, Nigeria. A subsequent review in a few years time of our additional experience with the use of diode laser would be appropriate, as the pool of patients that would have been treated by then would be larger and the period of follow up observation longer as well. Its use in refractory glaucoma has not been demonstrable by us so far. Its numerous logistic and cost advantages are highly impressive.

\section{ACKNOWLEDGMENT}

We wish to thank Professor (Mrs) A. Abiose, our retina teacher for her encouragement in making this work a reality. We also thank our various colleagues within and outside our hospital for giving us the opportunity to share in the management of these patients. Mr. Egbogu Onyih helped us with the preparation of this manuscript with great diligence.

\section{REFERENCES}

1. Balles MW; Puliafito CA; D’ Amico DJ, et al. Semiconductor diode laser photocoagulation in retinal vascular disease. Ophthalmology 1990; 97: 1533-61.

2. Haller JA; Lim JI; Goldberg MF. Pilot trial of transscleral diode laser retinopexy in retinal detachment surgery. Arch Ophthalmol 1993; 111: 952-6.

3. Hennis HL; Stewart WC. Semiconductor diode laser transscleral cyclophotocoagulation in patients with glaucoma. Am J Ophthalmol 1992; 113: $81-5$

4. Sasoh M; Smiddy WE. Diode laser endophotocoagulation. Retina 1995; 15: 388-393

5. Ulbig MW, Hamilton AM, Comparative use of diode and argon laser for parentinal photocoagulation in diabetic retinopathy. Ophthalmology 1993 Oct; (5): 457-62 
6. Tewari HK, Gupta V, Kumar A, Vermal L. Efficacy of diode laser for managing diabetic macular oedema. Acta Ophthalmol Scand 1998 Jun; $76(3)$ : 363-6.

7. Farber MD; Jampol LM; Fox P, et al. A randomised clinical trial of scatter photocoagulation of proliferative sickle cell retinopathy. Arch Ophthalmol 1991; 109: 363-367.

8. Ulbig MW; McHugh DA; Hamilton Am. Diode laser photocoagulation for diabetic macular oedema Br. J. Ophthalmol 1995: 79 (4): $318-21$.

9. Guyer DR, Duker JS, Puliafiato CA. Indocyanine green Angiography and DyeEnhanced Diode laser photocoagulation. Seminars on Ophthalmol 1992; 7 (3): 172-176.

10. Central Retinal Vein Occlusion Study Group. A randomised trial of early panretial photoco-agulation for Ischaemic central vein occlusion.

Ophthalmology 1995; 102: 1434-1444.

11. Brod RD; Flynn HW; Lightman DA. Asymptomatic rhegmatogenous retina detachment. Arch Ophthalmol. 1995; 113: 1030-1032. 